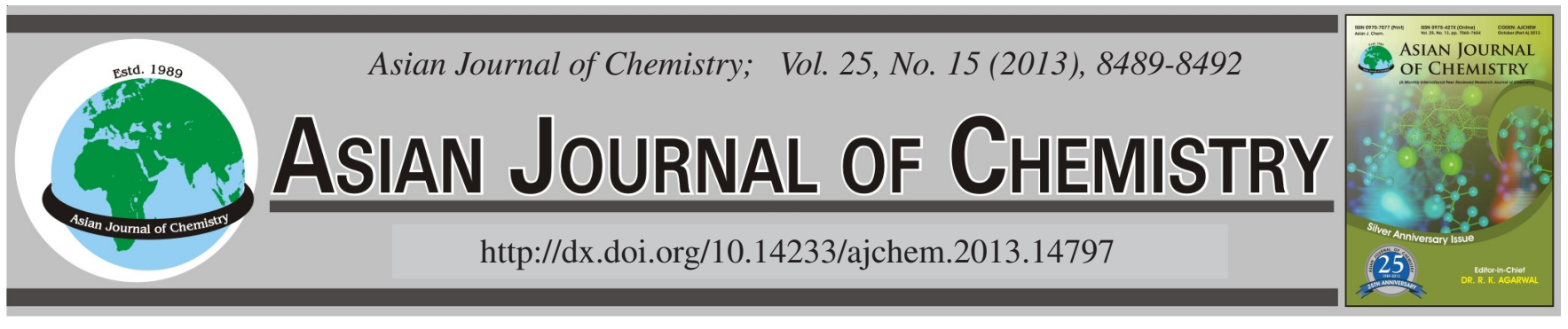

\title{
Chemical Study of Extracts of Siphonochilus aethiopicus (Schweinf.) B.L. Burtt (Zingiberaceae) from Benin
}

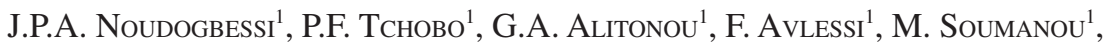 \\ P. Chalard ${ }^{2}$, G. Figueredo ${ }^{3}$, J.C. ChalChaT ${ }^{4}$ and D.C.K. SOHOUNHLOUE ${ }^{1, *}$
}

\begin{abstract}
${ }^{1}$ Unité de Recherche sur les Extraits Végétaux, Laboratoire d'Etude et de Recherche en Chimie appliquée, Ecole Polytechnique d'AbomeyCalavi, Université d'Abomey-Calavi 01 BP 2009 Cotonou, République du Bénin

${ }^{2}$ Laboratoire de Chimie des Hétérocycles et des Glucides, Clermont Université, ENSCCF, EA 987, BP 10448, F-63000 Clermont-Ferrand, France ${ }^{3}$ Laboratoire d'Analyse des Extraits Végétaux et des Arômes (LEXVA Analytique) 460 Rue du Montant, 63110 Beaumont, France

${ }^{4}$ Laboratoire de Chimie des Huiles Essentielles, Université Blaise-Pascal, Clermont-Ferrand II, Campus des Cézeaux, 63177 Aubière Cedex, France
\end{abstract}

*Corresponding author: E-mail: ksohoun@bj.refer.org; dominique.sohounhloue@uac.bj

(Received: 10 November 2012;

Accepted: 24 August 2013)

AJC-13979

\begin{abstract}
The chemical composition of essential oils, fatty acids and unsaponifiable of the limbs, foliars sheaths and rhizomes of Siphonochilus aethiopicus were studied by GC/MS. In petroleum ether extracts, the lipidic fractions are marked by significant rates ( 7.41 to $23.45 \%)$ of fatty acids in $\mathrm{C}_{18}$. The majority of unsaponifiable compounds from the limbs, foliars sheaths and rhizomes of S. aethiopicus are essentially consist of terpenoïds accompanied by heneicosane (6.2 to $21.6 \%$ ). Otherwise, S. aethiopicus contains varied rates of catechic saponins, tanins and leucoanthocyanes in its organs.

Key Words: Fatty acids, Insaponifiables, Leucoanthocyanes, Terpenoïds.
\end{abstract}

\section{INTRODUCTION}

Since the ancient period, the volatile extracts of the aromatic plants were sought for their biological properties. These plants were frequently used in traditional medicine for therapeutic purposes especially to relieve the cutaneous affections, respiratory disorders, digestive and cardiovascular diseases etc. Other biological properties of plants (antiradical and antiinflammatory power) generated interesting applications in chemical industry, in cosmetic and in pharmaceutical industry. S. aethiopicus (Zingiberaceae) is a fragrant aromatic plant of tropical Africa savannas. It is used as spices in the dishes flavouring by the Igede people of Nigeria ${ }^{1}$. In Benin, this plant is one of the endangered botanical species. It grows spontaneously state and appears as a plant less referred in the literature.

Some work has highlighted the biological activities of $S$. aethiopicus extracts. Makhuvha et al. ${ }^{2}$ used a set "starch gel horizontal electrophoresis" to study the genetic diversity of $S$. aethiopicus between a spontaneous natural population and individuals cloned by the same species, intended for the marketing. The cyclooxygenase inhibitory activity of ethanol and aqueous extracts of $S$. aethiopicus was tested by Lyndy et al. ${ }^{3}$. Lindsey et $a l .{ }^{4}$ showed that $S$. aethiopicus calms the menstrual pains by cyclooxygenase inhibition of prostaglandin biosynthesis. Zschocke et al..$^{5}$ reported the importance of the substitution strategy of the parts of medicinal plants for their preservation over a long period in South Africa. More recently, researchers ${ }^{6}$ have isolated and identified in 2002 through Nuclear Magnetic Resonance (NMR) high-field two furanoterpenoïc compounds: $4 \mathrm{a} \alpha \mathrm{H}-3,5 \alpha, 8 \mathrm{a} \beta$-trimethyl-4,4a,9tetrahydro-naphtho[2,3-b]-furan-8-one et 2-hydroxy-4a $\alpha H$ 3,5 $\alpha, 8 \mathrm{a} \beta$-trimethyl-4,4a,9-tetrahydronaphtho[2,3-b]-furan-8one. They were also interested in the changes of chemical composition and biological activity due to S. aethiopicus storage $^{7}$. Igoli and Obanu ${ }^{1}$ have isolated volatile components from the matrix of fresh and roasted samples of S. aethiopicus by solvent extraction and vacuum distilled. They made a quantitative determination of the volatiles components in the distillate by GC/FID and organoleptic examination by GC/ Olfactometry. They have identified sesquiterpenes as major components of fresh wild S. aethiopicus ${ }^{1}$. Other researchers ${ }^{8-10}$ relating $S$. aethiopicus biological activities have been reported in the literature.

Due to the importance which dresses this plant in traditional medicine of Africa in the South of Sahara and in Benin in particular, it is timely to investigate the chemical constituents of its cellular reserves. For that purpose, the present work 
mainly focused on the determination by GC/MS of fatty acids obtained after saponification and unsaponifiable constituents contained in limbs, leaf sheaths and rhizomes of S. aethiopicus from Benin.

\section{EXPERIMENTAL}

Limbs, leaf sheaths and rhizomes of S. aethiopicus were collected in september 2007 in a wild state in Manigri (Northern Benin). In the laboratory, the rhizomes were washed to remove the sand and all plant material was kept between 18 and $22{ }^{\circ} \mathrm{C}$. To extract fatty acids, limbs, leaf sheaths and rhizomes of $S$. aethiopicus, become dry, were transformed into powder to a crusher IKA WERK type MF 10 BASIC. The powders obtained were sieved to particle sizes 0.335 and 0.600 $\mathrm{mm}$. A voucher specimen of each part of S. aethiopicus has been deposited in Abomey-Calavi University National Herbarium.

Extraction of unsaponifiable compounds and fatty acids (FA): $15 \mathrm{~g}$ of powder (limbs, leaf sheaths and rhizomes) were treated twice successively with $100 \mathrm{~mL}$ of petroleum ether $\left(40-65^{\circ} \mathrm{C}\right)$ under magnetic stirring at room temperature for $1 \mathrm{~h}$. After filtration and evaporation of the solvent under reduced pressure, the extract was dried then weighed. The extraction yield was established by calculating the average of three replicates.

$0.5 \mathrm{~g}$ of the extract was saponified with $25 \mathrm{~mL}$ of ethanolic solution of potassium hydroxide $(2 \mathrm{~N})$ by refluxing for $1.5 \mathrm{~h}$. After cooling, it was added $50 \mathrm{~mL}$ of distilled water and the unsaponifiable matter were extracted with $3 \times 50 \mathrm{~mL}$ of cyclohexane. The soap solution produced was acidified $\left(\mathrm{H}_{2} \mathrm{SO}_{4} ; 98 \%\right)$ until the precipitation of fatty acid $(\mathrm{pH}=5$ to $6)$. These fatty acid released were extracted with $3 \times 50 \mathrm{~mL}$ of diethyl ether ${ }^{11-13}$.

The fatty acids were transformed into their methylic esters by addition of a methanolic solution at $10 \%$ of $\mathrm{BF}_{3}{ }^{14}$ and the methylic esters were extracted by the cyclohexane for analysis by GC/MS. The fatty acid yields and unsaponifiables matter relative to the mass of plant material used or to that of the petroleum ether crude extract are reported in Table- 2 .

GC/FID: The extracts were analyzed on a HewlettPackard gas chromatograph Model 6890, equiped with a DB5 MS column $(30 \mathrm{~m} \times 0.25 \mathrm{~mm}, 0.25 \mu \mathrm{m})$, programming from $50{ }^{\circ} \mathrm{C}$ ( $5 \mathrm{~min}$ ) to $300^{\circ} \mathrm{C}$ at $5{ }^{\circ} \mathrm{C} / \mathrm{min}, 5 \mathrm{~min}$ hold. Hydrogen as carrier gas $(1.0 \mathrm{~mL} / \mathrm{min})$; injection in split mode $(1: 60)$; injector and detector temperature: 280 and $300{ }^{\circ} \mathrm{C}$, respectively. Each extract is diluted in hexane: 1/30.

GC/MS: The extracts compositions were analyzed on a Hewlett-Packard gas chromatograph Model 5890, coupled to a Hewlett-Packad MS model 5871, equipped with a DB5 MS column $(30 \mathrm{~m} \times 0.25 \mathrm{~mm}, 0.25 \mu \mathrm{m})$, programming from 50 ${ }^{\circ} \mathrm{C}$ (5 min) to $300{ }^{\circ} \mathrm{C}$ at $5{ }^{\circ} \mathrm{C} / \mathrm{min}, 5 \mathrm{~min}$ hold. Helium as carrier gas $(1.0 \mathrm{~mL} / \mathrm{min})$; injection in split mode $(1: 30)$; injector and detector temperature, 250 and $280{ }^{\circ} \mathrm{C}$, respectively. The MS working in electron impact mode at $70 \mathrm{eV}$; electronmultiplier: $2500 \mathrm{eV}$; ion source temperature: $180{ }^{\circ} \mathrm{C}$; mass spectra data were acquired in the scan mode in $\mathrm{m} / \mathrm{z}$ range 33-450.

The compounds determined in various essential oils by CG/FID were identified by comparison between their indices of retention and those of reference components in the literature. These compounds identified by GC/FID are confirmed by GC/SM by comparing their spectra of mass with those of reference substances ${ }^{15-23}$.

Identification of saponins, tannins catechetical, leucoanthocyanes, oses and holosides, mucilages: The phytochemical screening was made according to the standard technical described by Paris and Moyse ${ }^{24}$, Bouquet ${ }^{25}$ and Debray et al. ${ }^{26}$.

Saponins: A decoction was prepared during $0.5 \mathrm{~h}$ from $2 \mathrm{~g}$ of plant powder and $100 \mathrm{~mL}$ of distilled water. After

\begin{tabular}{|c|c|c|c|c|c|c|}
\hline \multicolumn{7}{|c|}{$\begin{array}{l}\text { TABLE-1 } \\
\text { FATTY ACID AND UNSAPONIFIABLES YIELDS OF LIMBS, LEAF SHEATHS AND RHIZOMES OF S. aethiopicus }\end{array}$} \\
\hline & \multicolumn{3}{|c|}{ Fatty acid yield of the plant material } & \multicolumn{3}{|c|}{ Fatty acid yield of petroleum ether extracted } \\
\hline & $\mathrm{L}(\%)$ & Ls $(\%)$ & $\mathrm{Rz}(\%)$ & $\mathrm{L}(\%)$ & Ls (\%) & $\mathrm{Rz}(\%)$ \\
\hline FA & 0.3 & 0.1 & 0.8 & 6.2 & 25.6 & 27.8 \\
\hline Un & 2.3 & 0.2 & 0.4 & 56.0 & 51.2 & 13.9 \\
\hline
\end{tabular}

TABLE-2

FATTY ACID COMPOSITION OF THE LIMBS, LEAF SHEATHS AND RHIZOMES EXTRACTS OF S. aethiopicus

\begin{tabular}{|c|c|c|c|c|c|}
\hline Fatty acid & KI & $\mathrm{R}_{\mathrm{t}}(\min )$ & $\mathrm{L}(\%)$ & Ls $(\%)$ & $\mathrm{Rz}(\%)$ \\
\hline Capric acid $\left(\mathrm{C}_{10: 0}\right)$ & 1522 & 27.4 & 2.5 & - & - \\
\hline Myristic acid $\left(\mathrm{C}_{14: 0}\right)$ & 1723 & 31.9 & 1.7 & - & 0.4 \\
\hline Palmitic acid $\left(\mathrm{C}_{16: 0}\right)$ & 1925 & 36.0 & 13.0 & 25.8 & 13.3 \\
\hline Margaric acid $\left(\mathrm{C}_{17: 0}\right)$ & 2025 & 37.8 & - & 1.5 & 11.0 \\
\hline Linoleic acid $\left(\mathrm{C}_{18: 2(9,12)}\right)$ & 2091 & 39.1 & 7.1 & 20.4 & 15.7 \\
\hline Oleic acid $\left(\mathrm{C}_{18: 1}\right)$ & 2098 & 39.3 & 11.5 & 23.5 & 14.9 \\
\hline Stearic acid $\left(\mathrm{C}_{18: 0}\right)$ & 2125 & 39.7 & - & 7.4 & 2.7 \\
\hline Arachidic acid $\left(\mathrm{C}_{20: 0}\right)$ & 2326 & 43.2 & - & 1.3 & 0.8 \\
\hline Behenic acid $\left(\mathrm{C}_{22: 0}\right)$ & 2976 & 46.4 & - & - & 0.9 \\
\hline FA saturated & - & - & 17.2 & 36.9 & 29.1 \\
\hline FA unsaturated & - & - & 18.6 & 43.9 & 30.6 \\
\hline Total & - & - & 35.8 & 79.9 & 59.7 \\
\hline
\end{tabular}

$\mathrm{KI}=$ Kovats Indice, $\mathrm{R}_{\mathrm{t}}=$ retention time, $\mathrm{L}=$ Limbs, $\mathrm{Ls}=$ leaf sheaths, $\mathrm{Rz}=$ Rhizomes. 
filteration the obtained mixture, the filtrate was divided into 10 different volumes $(1,2,3$ and $10 \mathrm{~mL})$ in 10 calibrated tubes (internal diameter: $1.3 \mathrm{~cm}$ ). The content of each tube was adjusted to $10 \mathrm{~mL}$ with distilled water. After shaking each tube in an horizontal position for $15 \mathrm{~s}$, followed by a rest of 15 min in an upright position, the height of the foam supernatant was measured in $\mathrm{cm}$. When this height is close to $1 \mathrm{~cm}$ in the Xth tube, the foam index (I) is calculated by the following formula: $I=$ foam height $($ in $\mathrm{cm}$ ) in the Xth tube $\times 5 / 0$. $0 X$. The presence of saponins in the plant is confirmed when the value of the foam index is greater than 100 .

Catechin tannins: An aqueous infusion was prepared from $5 \mathrm{~g}$ of plant powder and $100 \mathrm{~mL}$ of boiling distilled water. After leaving for $15 \mathrm{~min}$, the mixture was filtered and infused obtained is completed to $100 \mathrm{~mL}$ with hot water. It was added to $30 \mathrm{~mL}$ of the infused (5\%), $15 \mathrm{~mL}$ of Stiasny reagent [formol $(40 \%)+\mathrm{HCl}(97 \%)]$. After $15 \mathrm{~min}$ in a water bath at $90^{\circ}$, a red precipitate, soluble in isoamylic alcohol, appeared indicating the presence of catechin tannins.

Leucoanthocyanes: They were identified by introducing into a test tube $5 \mathrm{~mL}$ of infused $(5 \%)$ and $5 \mathrm{~mL}$ of hydrochloric alcohol (ethanol $95^{\circ}+$ distilled water + hydrochloric acid $37 \%$ of equal volumes). The mixture was completed with $1 \mathrm{~mL}$ of isoamylic alcohol and then, heated to $90^{\circ}$ through a water bath. After fifteen minutes, it had developed a red-cerise tint (or purple) indicating the presence of leucoanthocyanes.
Oses and holosides: $5 \mathrm{~mL}$ of decoction $(10 \%)$ were evaporated to dryness and the residue obtained was treated with two to three drops of concentrated $\mathrm{H}_{2} \mathrm{SO}_{4}$, then, with three drops of ethanol saturated with thymol. A red colouring was observed indicating the presence of monosaccharides and holosides.

Mucilages: $1 \mathrm{~mL}$ of decoction realized previously was treated with $5 \mathrm{~mL}$ of absolute ethanol and the presence of mucilages were noticed by the appearance of a flaky precipitate.

\section{RESULTS AND DISCUSSION}

Fatty acids (FA) identified (Table-1) represent 0.1-0.8\% of the mass of plant material and 6.2-27.8 \% of the crude extract to petroleum ether. Fatty acids yields, obtained from the extracts of leaf sheaths $(25.6 \%)$ and rhizomes $(27.8 \%)$ of S. aethiopicus, are superior to that determined in the flowering tops $(13.1 \%)$ of Vetiveria nigritana (Benth.) by Champagnat et $a l^{27}$. Moreover, Champagnat et al. obtained $64.95 \%$ of $\mathrm{FA}^{27}$ whereas in the rhizomes of $S$. aethiopicus, the proportion of FA is $27.8 \%$. Only the crude extracts from the rhizomes contain less than $15.0 \%$ of unsaponifiable compounds (13.9 $\%)$. In limbs and leaf sheaths, this value is estimated at more than $50 \%$ (51.2 and $56 \%$ ).

According to the results (Table-2); 35.8 in $79.9 \%$ of the fatty acid were identified in limbs, leaf sheaths and rhizomes

\begin{tabular}{|c|c|c|c|c|c|c|}
\hline Compounds & $\mathrm{KI}_{\exp }$ & $\mathrm{KI}_{\mathrm{th}}$ & $\mathrm{R}_{\mathrm{t}}(\mathrm{min})$ & $\mathrm{L}(\%)$ & Ls $(\%)$ & $\mathrm{Rz}(\%)$ \\
\hline Sabinene & 974 & 969 & 11.6 & 0.1 & 0.2 & - \\
\hline$\beta$-Pinene & 978 & 974 & 11.9 & 0.1 & 5.1 & 3.8 \\
\hline$\beta$-Elemene & 1386 & 1389 & 23.9 & 0.3 & 1.0 & - \\
\hline Cyperene & 1408 & 1398 & 24.6 & 8.0 & 0.2 & 9.9 \\
\hline$\beta$-Caryophyllene & 1419 & 1417 & 24.7 & 7.3 & 2.2 & - \\
\hline$\alpha$-Humulene & 1455 & 1452 & 25.6 & 3.3 & 3.2 & - \\
\hline Allo-aromadendrene & 1459 & 1458 & 25.8 & 0.9 & 0.3 & - \\
\hline 9-Epi-(e)-caryryophyllene & 1466 & 1464 & 26.0 & 3.0 & - & 3.0 \\
\hline Germacrene-D & 1479 & 1484 & 26.3 & 1.9 & 1.4 & - \\
\hline$\beta$-Selinene & 1488 & 1489 & 26.6 & - & 0.2 & 5.8 \\
\hline Valencene & 1493 & 1496 & 26.7 & 0.7 & 0.7 & 1.2 \\
\hline Aciphyllene & 1496 & 1501 & 26.8 & 1.0 & - & 1.5 \\
\hline$\gamma$-Cadinene & 1514 & 1513 & 27.1 & - & 0.4 & - \\
\hline$\delta$-Cadinene & 1518 & 1522 & 27.2 & 2.1 & 0.5 & - \\
\hline 7-Epi- $\alpha$-selinene & 1523 & 1520 & 27.4 & 1.9 & 15.1 & 6.2 \\
\hline Germacrene-B & 1556 & 1559 & 28.1 & 2.1 & 0.8 & - \\
\hline Caryophyllene oxide & 1585 & 1582 & 28.9 & 25.7 & 2.5 & 2.8 \\
\hline Humulene epoxide II & 1606 & 1608 & 29.5 & 4.8 & 0.7 & 3.0 \\
\hline Epi- $\alpha$-cadinol & 1639 & 1638 & 30.0 & 1.8 & 0.6 & 2.5 \\
\hline Epi- $\alpha$-muurolol & 1641 & 1640 & 30.1 & - & 1.0 & 1.9 \\
\hline$\alpha$-Cadinol & 1654 & 1652 & 30.3 & 2.5 & 1.9 & 3.2 \\
\hline Selin-11-en-4- $\alpha$-ol & 1660 & 1658 & 30.4 & 2.1 & 0.3 & 17.7 \\
\hline Intermedeol & 1670 & 1665 & 30.8 & 2.8 & 27.8 & 13.7 \\
\hline 2,2,4,5,7,7-Hexamethylocta-3,5-diene & 1806 & - & 33.6 & 5.8 & - & 7.0 \\
\hline $6,10,14$-Trimethylpentadecan-2-one & 1840 & - & 34.3 & 3.8 & 0.6 & - \\
\hline Heneicosane & 2112 & 2100 & 39.5 & 14.6 & 21.6 & 6.2 \\
\hline
\end{tabular}

$\mathrm{KI}=$ Kovats Indice, $\mathrm{R}_{\mathrm{t}}=$ Retention time, $\mathrm{L}=$ Limbs, $\mathrm{Ls}=$ leaf sheaths, $\mathrm{Rz}=$ Rhizomes. 
of $S$. aethiopicus. Almost equivalent proportions in saturated and unsaturated fatty acid, in limbs (17.17 and 18.6\%) and rhizomes (29.1 and 30.6\%) were also observed. In leaf sheaths, the unsaturated fatty acids were the most dominant $(43.9 \%)$. However, 17.2 to $36.9 \%$ were constitued by saturated fatty acids. The most abundant are palmitic acid (13.0-25.8 \%), margaric acid $(11.0 \%)$ and stearic acid $(7.4 \%)$. Linoleic aid (7.1-20.4\%) and oleic acid (11.5-23.5\%) are the only unsaturated fatty acids identified in the plant organs.

It is important to note the appearance in the rhizomes a long chain fatty acid in small proportion [behenic acid (0.9\%)] and that of a saturated fatty acid having an odd number of carbon atoms [margaric acid $(11.0 \%)$ ]. The relatively low proportions of these last ones are evidence that the $\mathrm{C}_{20}$ fatty acid are uncommon in the plant kingdom ${ }^{23,28}$. Also, a total absence or low proportion of $\mathrm{C}_{10}$ fatty acid was reported in the organs of S. aethiopicus ${ }^{28}$. Indeed, capric acid (2.5\%), only acid $\mathrm{C}_{10}$, appeared in the limbs of $S$. aethiopicus but its presence was not noticed in the leaf sheaths and rhizomes.

GC/MS analysis revealed 19 to 27 constituents corresponding to 91.4 to $98.9 \%$ of the total weight of cyclohexane extracts from the limbs, leaf sheaths and rhizomes of $S$. aethiopicus. The oxygenated compounds, essentially sesquiterpenoics, are around 35.4 to $44.8 \%$. The main unsaponifiables (> $5 \%$ ) characteristics of the plant parts are $\beta$-pinene $(5.1 \%) ; \beta$ selinene $(5.8 \%) ; 2,2,4,5,7,7$-hexamethylocta-3,5-diene (5.8$7.0 \%)$; heneicosane $(6.2-21.6 \%)$; $\beta$-caryophyllene $(7.3 \%)$; cyperene (8.0-9.9\%); germacrene-A $(8.3 \%)$; 7-epi- $\alpha$-selinene (6.2-15.1\%); intermedeol (13.7-27.8\%), selin-11-en-4- $\alpha$-ol $(17.7 \%)$, caryophyllene oxide $(25.7 \%)$. Only two saturated hydrocarbons have emerged: heneicosane, most abundant in leaf sheaths $(21.6 \%)$ and hexatriacontane $(<1.0 \%)$ in limbs, leaf sheaths and rhizomes of $S$. aethiopicus (Table-3).

The characterization tests have shown the presence of saponins, catechic tannins, leucoanthocyanes, oses, holosides and mucilages (Table-4). Except the saponins which strong proportion was noticed in all S. aethiopicus organs, rhizomes also, were a potential reserve of catechins tannins, leucoanthocyanes and mucilages. Similarly, it was noticed a high presence of monosaccharids and holosides in the leaf sheaths.

\begin{tabular}{lccc}
\multicolumn{4}{c}{ TABLE-4 } \\
\multicolumn{4}{c}{ CHEMICAL FAMILIES IDENTIFIED } \\
IN Siphonochilus aethiopicus ORGANS \\
\cline { 2 - 4 } Chemical families & \multicolumn{3}{c}{ S. aethiopicus organs treated } \\
\cline { 2 - 4 } & Limbs & Leaf sheaths & Rhizomes \\
\hline Saponins (IF) & $+++(183.33)$ & $+++(225.00)$ & $+++(166.67)$ \\
Catechins tannins & ++ & + & ++ \\
Leucoanthocyans & ++ & + & +++ \\
Oses and holosides & 0 & +++ & 0 \\
Mucilages & ++ & ++ & +++ \\
\hline IF $=$ Index foam, abundant: +++, average:,++ very little: + , negative \\
test: 0.
\end{tabular}

\section{Conclusion}

This work has emerged some of the potential of chemical compounds in S. aethiopicus, a plant species rich in hydrocarbon compounds. Three fatty acids, commonly found in plant cells, were noted in the parts of the plant i.e., palmitic acid, oleic acid and linoleic acid. The unsaponifiable compounds of its organs were formed mainly by hydrocarbons and some oxygenated sesquiterpenes. The most importants were caryophyllene oxide $(25.7 \%)$ in limbs and intermedeol (13.7 to $27.8 \%$ ) in the rhizomes. The characterization tests revealed that S. aethiopicus organs were important sources of saponins. Catechic tannins, mucilages and leucoanthocyanes were particularly abundant in rhizomes.

\section{REFERENCES}

1. N.P. Igoli and Z. Obanu, Afr. J. Food Sci., 5, 541 (2011).

2. N. Makhuvha, B.E. Van Wyk, H. Van Der Bank and M. Van Der Bank, Biochem. System. Ecol., 25, 343 (1997).

3. L.J. Mc Gaw, A.K. Jäger and J. Van Staden, Phytother. Res., 11, 113 (1997).

4. K. Lindsey, A.K. Jäger, D.M. Raidoo and J. Van Staden, J. Ethnopharmacol., 64, 9 (1999).

5. S. Zschocke, T. Rabe, J.L.S. Taylor, A.K. Jäger and J. Van Staden, J. Ethnopharmacol., 71, 281 (2000).

6. C.W. Holzapfel, W. Marais, P.L. Wessels and B.E. Van Wyk, Phytochemistry, 59, 405 (2002).

7. G.I. Stafford, A.K. Jäger and J. Van Staden, J. Ethnopharmacol., 97, 107 (2005).

8. A.K. Jager and J. Van Staden, Phytochem. Rev., 4, 39 (2005).

9. C.A. Lategan, W.E. Campbell, T. Seaman and P.J. Smith, J. Ethnopharmacol., 121, 92 (2009).

10. G. Fouche, N. Nieuwenhuizen, V. Maharaj, S. Van Rooyen, N. Harding, R. Nthambeleni, J. Jayakumar, F. Kirstein, B. Emedi and P. Meoni, J. Ethnopharmacol., 133, 843 (2011).

11. AFNOR (NFT 60-205), Détermination de la teneur en matières insaponifiables.

12. J.P. Wolff, Manuel d'Analyse des Corps Gras. Paris: Azoulay (1968).

13. M. Gîrzu, A.P. Carnat and J.L. Chalard, Oléagineux, Corps Gras, Lipides, 2, 317 (1995).

14. L.D. Metcalfe and A.A. Schmitz, Anal. Chem., 33, 363 (1961).

15. P. Rösch, J. Popp and W. Kiefer, J. Mol. Struct., 480-481, 121 (1999).

16. R.P. Adams, Allured Publ. Corp., Carol Stream, IL (1995).

17. W. Jennings and T. Shibamoto, Academic Press, New-York (1980).

18. N.W. Davies, J. Chromatogr. A, 503, 1 (1990).

19. L. Doimo, R.J. Fletcher and B.R. D’Arcy, J. Essent. Oil Res., 11, 415 (1999).

20. J.P. Adams, Allured Publishing Corporation (2001).

21. F.W. McLafferty and D.B. Stauffer, The Willey NBS registry of Mass Spectral Data, John Wiley \& Sons, New York, edn. 2 (1989).

22. H. Van Den Dool and P.D. Kratz, J. Chromatogr. A, 11, 463 (1963).

23. A. Karleskind, Manuel des Corps Gras, Paris: Tec. \& Doc., Lavoisier (1992).

24. R. Paris and H. Moyse, Précis de matière médicinale, Masson, Paris (1969).

25. M. Bouquet, Travaux et documents de l'Orstom, Paris, 13 (1971).

26. M. Debray, H. Jacquemin, R. Razafindrambo, Travaux et documents de l'Orstom, Paris, 8 (1971).

27. P. Champagnat, G. Figueredo, A.P. Carnat, A. Carnat and J.P. Louis Lamaison, Oléagineux, Corps Gras, Lipides, 13, 190 (2006).

28. J. Bruneton, Pharmacognosie, Phytochimie, Plantes Médicinales, edn. 3, p. 125 (1999). 